\title{
青年期の自己志向的完全主義と対人ストレス・コーピング および精神的健康の関連
}

\author{
○岩㟝眞和（茨城キリスト教大学）・五十嵐透子（上越教育大学） \\ キーワード：自己志向的完全主義，対人ストレス・コーピング，精神的健康，青年期
}

\section{目 的}

本研究では，ライフサイクルのなかでもアイデンティティ の確立過程で心理的健康を損ねたり（及川・坂本, 2007), さ まざまな精神疾患を発症しや寸い発達段階である青年期を対 象に，自己志向的完全主義と対人ストレス・コーピングおよ び精神的健康との関連を検証した。なお “完全主義”に関す る心理学的研究では, 高い目標と達成に向けた努力を通じて, 環境適応や心理的健康に望ましい影響をおよぼす適応的側面 と, 高すぎる目標や理想イメージから常にネガティブな感情 を抱きやすい不適応的側面の両側面を考慮する必要性が指摘 されている (Enns \& Cox, 2002)。そのため, 本研究では福井 （2009）や源（2011）にならって，自己志向的完全主義傾向 を表す 2 因子を用いた類型化と, それに基づく分析を行った。 本研究により青年期の精神的健康の維持・増進や，完全主義 傾向の高さに伴う困難さを抱えた人々に対する健康心理学的 支援および予防教育に寄与する知見が得られると思われる。 以下に，先行研究より推測される 2 つ仮説を示す。

仮説 1 : 自己志向的完全主義の適応的側面 (完全性の追求) が高い人ほど対人関係をより円滑に営むための対人ストレ ス・コーピングを用いやすく，主観的幸福感も抱きやすい。

仮説 2 : 自己志向的完全主義の不適応的側面（不完全性一 の怖れ）が高い人ほど対人関係を回避する対人ストレス・コ ーピングを用いやすく，抑うつ傾向が高い。

\section{方 法}

2014 年 11 月下旬に 4 年制大学 2 校で, 講義終了後の集合 調査法による無記名式の質問紙調查を行い，計 377 名から回 答を得た（回収率 97.89\%)。質問紙は，性別と年齢を問うフ エイスシートと “自己志向的完全主義尺度” (福井・山下, 2012 ; 20 項目, 6 件法), “対人ストレス・コーピング尺度” （加藤，2001；34 項目，6 件法）を土田・五十嵐（2015）に ならって項目の文章表現を“現在形”に改めた尺度, Depression -Happiness Scale 邦訳版（土田，2014；25 項目 5 件法）で構 成した。なお，本研究の発表に際して開示す心゙き利益相反関 係にある法人や企業および団体等はなく，調査協力者に対し ても個人情報の保護やデータの管理, 調査協力の辞退も可能 であることなどを伝え，十分な倫理的配慮を行った。

\section{結 果}

<分析対象 > 得られた回答のうち, 久損值の多さや年齢の外 れ值から 53 名を除いた 316 名（有効回答率 $85.63 \%$; 男性 15 2 名, 女性 164 名）を分析対象とした。分析対象の平均年齢 は20.27 歳（ $S D=1.01$ 歳, range : 19-25 歳）であった。

＜各因子間の相関分析＞各因子間の関連を検証したところ, “完全性の追求” は“ポジティブ関係コーピング”と“主観 的幸福感” と弱い正の関連，“不完全性への怖れ” “齐ガテ イブ関係コーピング”と “抑うつ傾向”と弱い正の関連，“主 観的幸福感”との間で弱い負の関連をそれぞれ示した（Table 1)。以上の結果から，本研究の仮説 $1 \cdot 2$ は概㸚支持された。
Table 1 各因子間の相関分析結果

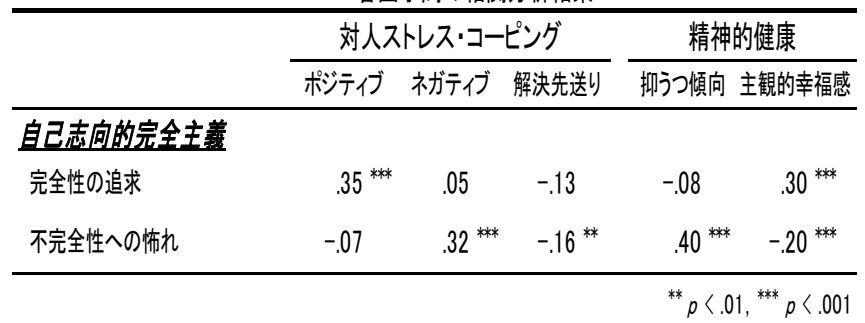

<自己志向的完全主義傾向の類型化 $>$ 自己志向的完全主義 の両因子の平均值を基準に対象を高低群（以下， $\mathrm{H}$ 群と $\mathrm{L}$ 群 と略記）に分け，2因子の組み合わせから“HH 群（完全性へ の追求と不完全性への怖れが共に平均值より高い群)”“HL 群（完全性への追求が高いが，不完全性への怖れは低い群）” “LH 群（完全性への追求が低いが，不完全性への怖れは高 い群)” “LL 群 (完全性への追求と不完全性への怖れが共に平 均值未満の群)”の 4 つに群分けした。

<自己志向的完全主義の各類型の特徵> 自己志向的完全主 義の 4 類型を独立変数, 他の諸因子を従属変数（計 5 因子） とする分散分析を行った結果, 全因子で要因の効果が有意で あった。多重比較（Tukey 法）の結果を Table 2 に示した。

Table 2 自己志向的完全主義の各類型の対人ストレス・コーピングと精神的健康の平均值と標準偏差

\begin{tabular}{|c|c|c|c|c|c|}
\hline $\begin{array}{l}\text { 1. HH群 } \\
(n=99)\end{array}$ & $\begin{array}{l}\text { 2. HL群 } \\
(n=68)\end{array}$ & $\begin{array}{l}\text { 3. LH群 } \\
(n=57)\end{array}$ & $\begin{array}{l}\text { 4. LL群 } \\
(n=87)\end{array}$ & F値 & 多重比較 \\
\hline$S D$ & $S D$ & $S D$ & $S D$ & & \\
\hline
\end{tabular}

\section{対人ストレス・コーピング}

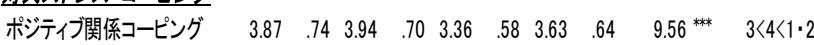

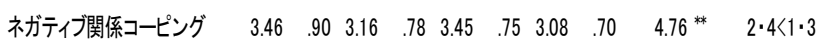

$\begin{array}{llllllllllll}\text { 解決先送りコーピング } & 3.71 & .90 & 4.03 & .78 & 3.88 & .69 & 4.02 & .92 & 2.644^{*} & 1<2 \cdot 4\end{array}$

\section{精神的煡康}

抑うつ傾向

$\begin{array}{llllllllll}2.94 & .88 & 2.25 & .71 & 3.11 & .86 & 2.46 & .80 & 16.96^{* * *} & 2 \cdot 4<1 \cdot 3\end{array}$

主観的幸福感

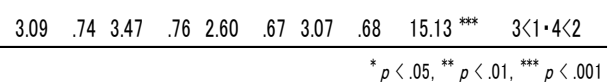

\section{考 察}

相関分析の結果，仮説 $1 \cdot 2$ が支持されるとともに自己志向 的完全主義の類型化に基づく分散分析により, (1) “完全性の 追求”が平均值より高いと “ポジティブ関係コーピング”を 取りやすい, (2) “不完全性への怖れ”が平均值より高いと“ネ ガティブ関係コーピング”を取りやすく抑うつ傾向も高い, (3)4 群で “完全性の追求” が平均值より高く “不完全性への 怖れ” が平均值未満の HL 群の主観的幸福感がもっとも高く, 反対の特徴を有する LH 群の主観的幸福感がもっとも低いと いう知見を得た。以上の結果から, 自己志向的完全主義が高 い人をより機能的かつ適応的な状態へと援助する際には, 自 己志向的完全主義の両側面のバランスのアセスメントを行っ た上で，自身の失敗や不完全さを過度に怖れないような支援 とともに，高い目標に向けて努力しようとする傾向は本人の “強み”として認めることの重要性が示唆された。

(IWASAKI Masakazu, IGARASHI Toko) 